\title{
Salivary Interleukin 6 and Sialic acid in Periodontitis
}

\author{
Jwan Ibrahim. Jawzali
}

$1 \mathrm{PhD}$. In Oral Biochemistry Lecturer in Basic science Department / College of Nursing- Hawler Medical University /Erbil/ Iraq.
Corresponding author: Jwan Ibrahim. Jawzal Emails: jwanjaw@yahoo.com jwanjawzali@gmail.com College email:jwanjaw@ nur.hmu.edu.krd

Received: August 26, 2017 Accepted: December 01, 2017
Aim: Periodontitis is the major multi -factorial chronic infectious oral diseases in dentate people. Sialic acid regulates innate immunity response that release cytokines. The study aimed to evaluate interleukin- 6 levels in periodontittsis and its relation to clinical features, total sialic acid and its fraction and total proteins to clarify its role. Material and Methods: The study was observational case-control study, carried out in periodontology clinic, College of Dentistry / Erbil /Iraq. A total of 60 participants were recruited in this study, They were divided into three groups: control group represent systemically and periodontally healthy subjects, clinically, diagnosed dentate periodontitis group and partial edentulous group.The data was collected through interview questionnaire, clinical periodontal examination, and biochemical tests for salivary; IL-6.total sialic acid and its fraction, and salivary total proteins Statistical analysis was done by statistical Package for Social Sciences. Results: Statistical analysis showed a significant $(P \leq 0.01)$ highest value of total sialic acid in periodontitis. While the highest value of IL- 6 was in partial edentulous group. Old ages increased salivary IL-6 significantly. In periodontitis there was significantly association of IL- 6 with probe pocket depth, mobility scores of teeth, protein bonund sialic acid and significant negative association with lipid bound sialic acid in the precipitate. While in partial edentulous IL-6 associated significantly with gingival index and free sialic acid in precipitate and negatively with probe pocket depth. Conclusions: Salivary sialic acid and IL- 6 are periodontitis biomarkers in dentate. Pleiotropic role of IL- 6 can be diagnosed by sialic acid levels. It depends on age, (which affects number of teeth and salivary flow rate), and treatment conditions.

Keywords: Sialic acid. Periodontal inflammation and IL-6. 


\section{Introduction}

Periodontitis is the major chronic inflammatory oral disease in dentate people. It is a multi -factorial influenced by genetics as well as by the environment ${ }^{1}$. It is initiated by gram negative bacteria that secrete various cytokines from lipo-polysaccharides ${ }^{2}$. Improper or exuberant immune response lead directly toward over production of inflammatory cytokines that lead to deleterious inflammatory processes and destruction of the periodontal tissue and alveolar bone, consequently periodontal attachment loss ${ }^{3}$.

Interleukin-6 (IL-6) is an important cytokine involved in the regulation of host response to tissue injury and infection ${ }^{4}$. IL-6, produced locally in bone following stimulation by IL-1 and tumor necrosis factor (TNF) 5 , by a variety of cells, such as monocytes, fibroblasts, osteoblasts, and vascular endothelial cells in response to inflammatory challenges.

IL-6 activity in inflammation is considered double-edged (a pleiotropic cytokine), that may enhance or suppress inflammatory bone destruction. Traditionally IL- 6 has been considered to be a pro-inflammatory mediator, because it is induced by IL- 1 and TNF- $\alpha$ early in the inflammatory cascade and stimulates expression of acute-phase proteins that have anti-inflammatory properties ${ }^{6}$

Previous studies reported anti-inflammatory properties of IL-6; it can increase the production of tissue inhibitors of matrix metalloproteinases (TIMP), suppresses IL-1 expression, can induce the synthesis of $\mathrm{IL}-1$ receptor antagonist (IL-1Ra) and the release of soluble TNF receptors ${ }^{4}$. Recent studies demonstrate that IL- 6 deficient in many typical pro-inflammatory properties and exert a number of anti-inflammatory activities such as; indirect stimulation and production of; collagenase, and matrix metalloproteinase, or stromelysin, inhibition superoxide production, and suppression spontaneous IL-1-mediated degradation of cartilage matrix ${ }^{5}$.

Therefore individual variability in the ability to synthesize and release of IL-6 may modulate the susceptibility, development, and progression of a number of autoimmune and inflammatory diseases (periodontal diseases) which are recently reported to be associated with IL-6 deregulation ${ }^{6}$

Sialic acids are a family of nine carbon acidic monosaccharide. An important function of host sialic acid is to regulate innate immunity ${ }^{7}$. Bacteria with capsular polysaccharide (such as gram negative bacteria) containing sialic acid interacts with component of the hosts nonspecific immune response, may modulate the ability of the host to mediate an immune response by affecting the release of cytokine molecules thereby disrupting the coordination of the hosts cell-mediated immune response ${ }^{8}$. Pro-inflammatory cytokines such as interleukin-1, interleukin-6, and tumor necrosis factor- $\alpha$ stimulated to produce acute-phase glycol-proteins with sialic acid as a component of the oligosaccharide side chain ${ }^{9}$. Sialic acid is a stable and representative marker of the overall acute-phase response ${ }^{10}$.

The current criteria for assessment of periodontal tissues surrounding teeth were based on clinical and radiographic changes. Saliva is a non-invasive suitable environment for biochemical and immunological analysis and can be an early indicator for detection of active periodontal disease ${ }^{11}$. 
Imbalance between pro- and anti-inflammatory cytokines could be involved in the initiation and progression of chronic periodontitis ${ }^{12}$. There are conflicting reports on differences in salivary IL-6 levels between chronic periodontitis and healthy subjects. Studies are required for clarifications the roles of IL-6 in periodontitis progression and identifying factors that may affect the role of IL-6. Therefore this study conducted to evaluate interleukin-6 levels in periodontitis and its relation to clinical features and inflammable salivary biomarkers; total sialic acid and its fraction and total proteins to identify its role in disease progression.

Methods and patients: The study was observational case-control study. It was arried out in the dental teaching clinic - College of Dentistry / Hawler Medical University. During the period of $1^{\text {st }}$ August 2009 up to $30^{\text {th }}$ September 2009.

Participants (Study populations): A total of 60 convenient samples recruited in this study, with age ranged between 18 and 70 years of both genders. They were screened for periodontal health status and divided into three groups; first were 20 participants free from periodontal disease and regarded as control group, second 32 dentate out patients group, diagnosed with chronic periodontitis disease,(had $>3-\geq 7 \mathrm{~mm}$ pockets depth), according to the classification of the periodontal diseases issued by the American Academy of Periodontology ${ }^{13}$, in 1999, third group were 8 partial edentulous periodontitis patients with history of treatment.

Inclusion criteria: Healthy participants systemically and with no history of periodontal and antibiotic treatment prior to the study for three month.

Exclusion criteria: Pregnant and lactating women and patients with systemic diseases.

Sampling technique: A structured questionnaire (interview form) was used to collect data by asking the studied population about social and behavior factors included; age, sex, occupation, educational levels, smoking status, oral hygiene habits (frequency of tooth brushing, use of dental floss), and use of medications. All participants were informed on the procedure and their consents had been taken.

Clinical measurement: The clinical periodontal examinations were carried out by the trained dentist and calibrated by the supervisor of the teaching clinic. The measurements included; bleeding on probing by Saxer and Mühlemann ${ }^{14}$, probe pocket depth (PD) was measured with (Williams probe), for all teeth from gingival margin to the base of pocket at four sides (labial/buccal, lingual/palatal, mesial and distal surfaces), per teeth, mobility of teeth classified by Carranza and Takei ${ }^{15}$, and miss of teeth. Classifications of The (AAP) ${ }^{13}$ were used for identifying the severity of disease; probing depths $>3 \&<5 \mathrm{~mm}$ (mild pockets), $\geq 5 \&<7 \mathrm{~mm}$ (moderate pockets) and $\geq 7 \mathrm{~mm}$ (sever pockets). The gingival index (GI) and plaque index $(\mathrm{Pl})$ scores were recorded, using criteria of (Löe, 1987) ${ }^{16}$

\section{Saliva collection}

Saliva samples (prior to the clinical measurements) were collected from all subjects between 9 and 11 hours am. Spitting method ${ }^{17}$ was used for collection un-stimulated whole saliva. Patients were prevented from eating, drinking, and oral hygiene for $2 \mathrm{~h}$ before collection. The samples were stored at $-20^{\circ} \mathrm{C}$ for one hour, then centrifuged immediately at (10000) $\mathrm{g}$ and at $4^{\circ} \mathrm{C}$ for 20 minutes to obtain supernatant and precipitate. Both fractions were stored at $-20 \mathrm{C}^{0}$ for analysis. 
Biochemical tests: This included salivary IL-6 Enzyme-linked immunosorbent assay (ELISA) kits (Abeckman coulter manufacture). Total sialic acid (TSA) and free sialic acids (FSA) were measured with modified thiobarbituric acid method of Skoza and Mohos $^{18}$. Extraction and determination of lipid -bound sialic acid (LSA) by Masami19. Determination of sialic acid bound to total proteins (PSA) by Shetty and Pattabiraman ${ }^{20}$, salivary total proteins by Lowry method Davidson College ${ }^{21}$.

Statistical analysis: The statistical Package for Social Sciences (SPSS, Version 18) was used for data analysis by parametric and non parametric tests for normal and abnormal distribution of variables checked by shapiro-wilk test. Analysis of variance (ANOVA-test) to compare between three or more means and t-test to compare between two means. Correlation coefficient for measuring correlation between quantitative data and Eta test for measuring association between nominal and interval. Binary logistic regression for odds ratios measurement. A p-value of $\leq 0.05$, and $\leq 0.01$ were considered statistically significant and high significant respectively.

\section{Results}

The studied population composed of 32 (53.3\%) periodontitis, 20 (33.3\%) participant as control and $8(13.3 \%)$ partial edentulous patients with teeth miss more than (10).

\section{Salivary mean levels of IL-6, total sialic acid and total protein}

Statistical analysis showed a significant $(P \leq 0.01)$ difference in the means of total sialic acid and total protein between periodontitis, control, and partial edentulous group. Post Hoc Least Significant Difference (LSD) test showed significant $(P \leq 0.01)$ difference of periodontitis with control and partial edentulous groups in sialic acid, while partial edentulous showed similarity with control group. Total salivary proteins, in periodontitis differ significantly $(P \leq 0.05)$ with control but not with partial edentulous. There was also a significant $(P \leq 0.01)$ difference in the means of $I L-6$ between the groups. Post Hoc (LSD) test showed significant highest value $(P \leq 0.01)$ value of IL-6 in partial edentulous compare to periodontitis and control groups.

Table 1. Mean levels of salivary; IL-6, protein, and total sialic acid

\begin{tabular}{lcccc}
\hline Groups & No. & $\begin{array}{c}\text { IL-6 }(\mathrm{pg} / \mathrm{ml}) \\
\text { Mean } \pm \text { S.E }\end{array}$ & F-value & P-value \\
\hline Periodontitis & 32 & $26.13 \pm 7.4$ & 18.7 & $0.00^{* *}$ \\
\hline Control & 20 & $1.7 \pm 8.3$ & & \\
\hline Partial edentulous & 8 & $66.35 \pm 8.3$ & F-value & P-value \\
\hline Groups & No & $\begin{array}{c}\text { Salivary protein } \\
\text { Mean } \pm \text { S.E. }\end{array}$ & 11.5 & $0.00^{* *}$ \\
\hline Periodontitis & 32 & $6.6 \pm 0.34$ & & \\
\hline Control & 20 & $4.12 \pm 0 . .27$ & F value & P-value \\
\hline Partial edentulous & 8 & $5.7 \pm 0.47$ & 16.96 & $0.00^{* *}$ \\
\hline Groups & No. & Total sialic acid (mg/l) \\
Mean \pm S.E.
\end{tabular}

${ }^{* *}(P \leq 0.01), *(P \leq 0.05)$, No $=$ Number 
Relation of ages with salivary IL-6 and cases: Statistical analysis showed a significant correlation of IL-6 with ages and significant differences of IL- 6 among age groups. There was also significant relation and differences of ages among cases. Binary Logistic regression showed a significant little increase risk of IL-6 levels in old ages and in partial edentulous, Table (2).

Table 2. Relation and differences of ages with salivary (IL-6) and cases

\begin{tabular}{lcccccccc}
\hline $\begin{array}{l}\text { Age groups } \\
\text { (Years) }\end{array}$ & $\begin{array}{l}\text { IL-6 }(\mathrm{pg} / \mathrm{ml}) \\
\text { Mean } \pm \text { S.E. }\end{array}$ & No. & $\begin{array}{c}\text { Value } \\
\text { of R }\end{array}$ & P-value F-value P-value & B & 95\% Cl \\
\hline $18-44$ & $14.9 \pm 3.7$ & 36 & 0.37 & $0.003^{* *}$ & -2.3 & $0.028^{*}$ & $1.024^{*}$ & $1.0-1.1$ \\
\hline $45-75$ & $35.9 \pm 8.3$ & 24 & & & & & & \\
\hline $\begin{array}{l}\text { Groups of the study } \\
\text { (cases) }\end{array}$ & Mean of ages \pm SE & No & $\begin{array}{c}\text { Eta } \\
\text { test }\end{array}$ & Degree F-value P-value & B & $95 \% \mathrm{Cl}$ \\
\hline Periodontitis & $39.5 \pm 2.23$ & & 0.79 & Strong & 3.5 & $0.037^{*}$ & $1.03^{*}$ & $1.0-1.06$ \\
\hline Control & $34.9 \pm 3.5$ & & & & & & & \\
\hline Partial ed. & $49.5 \pm 2.8$ & & & & & & & \\
\hline Total & $39.3 \pm 1.8$ & & & & & & & \\
\hline
\end{tabular}

$(P \leq 0.01) \star \star,(P \leq 0.05) \star, R=$ Pearson's correlation coefficient, $B=$ odds ratio, $\mathrm{Cl}=$ Confident interval, ed. = edentulous

\section{Relation between IL-6 and periodontal health status in periodontitis:}

Table (3) shows significant positive correlations of IL-6 and protein bound to sialic acid (PSA) with probe pocket depth (PD). There was also high relations of (IL-6) and total sialic acid with mobility of teeth. Statistical analysis showed significant differences in the means of IL-6 and PSA among groups of probe depth (PD), and TSA among teeth mobility scores.

Table 3. Association of IL-6 and sialic acid with probe pocket depth and teeth mobility in periodontitis

\begin{tabular}{|c|c|c|c|c|c|c|}
\hline Prop depth of teeth (PD) in $\mathrm{mm}$ & $\begin{array}{l}\mathrm{IL}-6(\mathrm{pg} / \mathrm{ml}) \\
\text { Means } \pm \text { S.E. }\end{array}$ & No. & Value of $R$ & P-value & $\begin{array}{l}\text { F-Test } \\
\text { Value }\end{array}$ & $\begin{array}{l}\text { P-value of } \\
\text { Difference }\end{array}$ \\
\hline Mild $>3-<5$ & $20.7 \pm 4.9$ & 17 & 0.37 & $0.039 *$ & 6.5 & $0.005^{\star}$ \\
\hline Moderate $\geq 5-6$ & $26.1 \pm 4.9$ & 13 & & & & \\
\hline Sever $\geq 7$ & $53.0 \pm 37.75$ & 2 & & & & \\
\hline Total & $26.14 \pm 3.9$ & 32 & & & & \\
\hline Prop depth (PD) in mm & $\begin{array}{l}\text { PSA Means } \pm \\
\text { S.E.(mg/l) }\end{array}$ & No. & Value of $R$ & P-value & $\begin{array}{l}\text { F-Test } \\
\text { Value }\end{array}$ & $\begin{array}{l}\text { P-value of } \\
\text { Differences }\end{array}$ \\
\hline Mild $>3-<5$ & $26.5 \pm 2.6$ & 17 & 0.52 & $0.002^{\star \star}$ & 15.1 & $0.001^{* *}$ \\
\hline Moderate $\geq 5-6$ & $30.2 . \pm 2.9$ & 13 & & & & \\
\hline Sever $\geq 7$ & $79.5 \pm 29.4$ & 2 & & & & \\
\hline Total & $31.3 \pm 17.9$ & 32 & & & & \\
\hline Mobility scores & $\begin{array}{l}\mathrm{IL}-6(\mathrm{pg} / \mathrm{ml}) \\
\text { Means } \pm \text { S.E. }\end{array}$ & No. & Value of $R$ & P-value & F-value & $\begin{array}{l}\text { P-value of } \\
\text { difference. }\end{array}$ \\
\hline 0 & $16.44 \pm 5.3$ & 9 & 0.37 & $0.038^{*}$ & 1.76 & 0.176 \\
\hline 1 & $23.9 \pm 21.6$ & 14 & & & & \\
\hline 2 & $40.3 \pm 10.9$ & 7 & & & & \\
\hline 3 & $36.0 \pm 15.0$ & 2 & & & & \\
\hline Total & $26.13 \pm 3.9$ & 32 & & & & \\
\hline Mobility scores & $\begin{array}{c}\text { Total sialic acid }(\mathrm{mg} / \mathrm{l}) \\
\text { Means } \pm \text { S.E. }\end{array}$ & No. & Value of $R$ & P-value & F-value & $\begin{array}{l}\text { P-value of } \\
\text { difference. }\end{array}$ \\
\hline 0 & $100.6 \pm 28.9$ & 9 & 0.35 & $0.047 *$ & 6.0 & $0.003^{* \star}$ \\
\hline 1 & $87.7 \pm 4.4$ & 14 & & & & \\
\hline 2 & $130.3 \pm 15.5$ & 7 & & & & \\
\hline 3 & $145.1 \pm 18.7$ & 2 & & & & \\
\hline Total & $156.8 \pm 41.6$ & 32 & & & & \\
\hline
\end{tabular}

$*=(P \leq 0.05),{ }^{* *}=(P \leq 0.01), R-$ Pearson's correlation 


\section{Assosiation of IL- 6 in partially edentulous with periodontal health status}

Table (4) shows a negative correlation of IL-6 with probe pocket depth, and significant positive correlation of IL- 6 with gingival index $\mathrm{Gl}$ and significant difference of IL-6 among GI groups. There was also negative correlation of probe pocket depth with TSA $(-0.85, \mathrm{P}$ value $=0.1)$ and its fractions, while $\mathrm{Gl}$ showed positive significant correlation $\left(0.78, \mathrm{P}\right.$ value $\left.=0.05^{*}\right)$ with FSA in sediment of saliva .

Table 4. Association of IL-6 with probe pocket depth, and gingival scores

\begin{tabular}{|c|c|c|c|c|c|c|}
\hline $\begin{array}{l}\text { Prop depth of } \\
\text { teeth (PD) in } \mathrm{mm}\end{array}$ & $\begin{array}{l}\text { IL-6 }(\mathrm{pg} / \mathrm{ml}) \\
\text { Means } \pm \text { S.E. }\end{array}$ & No. & $\begin{array}{l}\text { Value of } \\
\text { Spearman }\end{array}$ & P-value of $R$ & $\begin{array}{l}\text { Kruskal-Test } \\
\text { Value }\end{array}$ & $\begin{array}{l}\text { P-value Sig. of } \\
\text { Difference }\end{array}$ \\
\hline Mild $>3-<5$ & $79.5 \pm 35.7$ & 4 & \multirow{3}{*}{-0.22} & \multirow{3}{*}{ No sig. } & \multirow{3}{*}{0.33} & \multirow{3}{*}{ No sig } \\
\hline Moderate $\geq 5-6$ & $53.3 \pm 19.9$ & 4 & & & & \\
\hline Total & $66.4 \pm 19.5$ & 8 & & & & \\
\hline $\begin{array}{l}\text { Groups of } \\
\text { Gingival Index }\end{array}$ & Means \pm S.E & & Spearman & $\begin{array}{l}\text { P-value of } \\
\text { spearman }\end{array}$ & Mann- & Whitney \\
\hline Moderate (1.1-2) & $42.8 \pm 14.2$ & 6 & \multirow{3}{*}{0.93} & \multirow{3}{*}{$0.01^{\text {** }}$} & \multirow{3}{*}{\multicolumn{2}{|c|}{$0.047^{\star}$}} \\
\hline Sever (2.1-3) & $136.9 \pm 31.9$ & 2 & & & & \\
\hline Total & $66.4 \pm 19.5$ & 8 & & & & \\
\hline
\end{tabular}

$*=(P \leq 0.05) ; * *=(P \leq 0.01)$

Correlation of IL- 6 with total sialic acid and its fractions among groups of studied population:

Statistical pearson's correlation showed a significant correlation of (IL-6) with protein bound sialic in supernatant $\left(r=0.468^{* *}\right)$, (Fig 1) and total salivary protein $\left(r=0.451^{* *}\right)$ in periodontitis, While lipid bound sialic acid in sediment showed significant $(P \leq 0.05)$ negative correlation $\left(r=-0.382^{*}\right)$ with (IL-6) in periodontitis (Fig 2) as well as free sialic acid in sediment of saliva showed a significant positive correlation (Spearman correlation value $=0.820^{*}$ ) with salivary IL-6 among partial edentulous group.

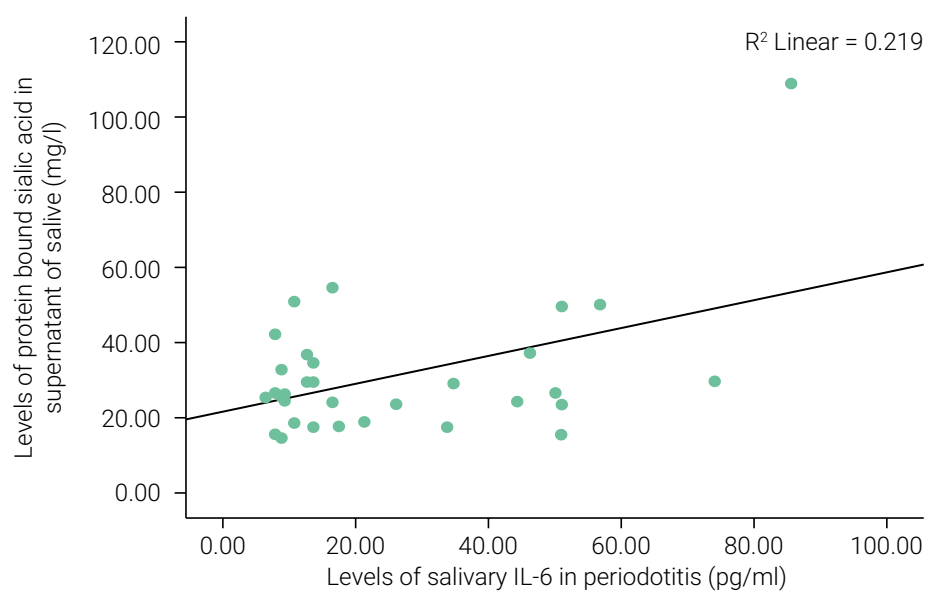

Figure 1. Correlation between salivary IL-6 and protein bound sialic acid in supernatant of saliva of periodontitis 


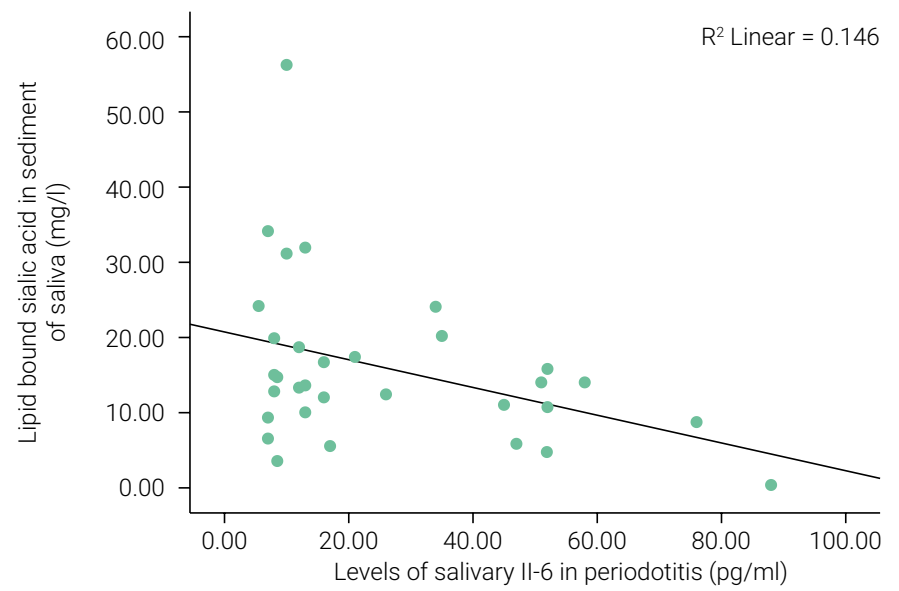

Figure 2. Inverse correlation between salivary IL-6 and lipid bound sialic acid in sediment of saliva of periodontitis patients

\section{Discussion}

\section{Salivary levels of IL-6, total sialic acid and total protein in periodontitise} and controls

Total salivary; sialic acid, protein and IL-6 showed significant high concentration in periodontitis patients compare to controls. This view pathogenesis role of increased salivary TSA levels in periodontal disease suggested by Shinohara et al.22 and can differentiate between periodontal disease and normal condition. High level of IL-6 is in line with previous studies (Elbersol and Cappelli23, Miller et al. ${ }^{24}$ ) who found that periodontitis patients have higher (IL-6) levels when compared to the periodontally healthy population. This result is in contrast with studies of Nibali et al. ${ }^{6}$ and Shaker and Hashem ${ }^{12}$ who found no significant difference in the levels of IL- 6 between chronic periodontitis and periodontally healthy subjects.

Significant difference in the level of total; protein, sialic acid and (IL-6) between periodontitis and control may be returned to virulence type of bacteria and its products in periodontitis, and change in biosynthesis and post translational glycosylation processes of the acute-phase glycoprotein in the liver as indicated a by significant positive and negative correlation of (IL-6) with, protein bound to sialic acid (PSA), and lipid bound sialic acid (LSA) in sediment respectively. Bacteria with virulence factor included either serotype lipopolysaccharide or specific antigen stimulates secretion of cytokines from monocytes that are modulated with sialic acid. This was in agreement with Soell et al. ${ }^{25}$ who stated that structurally related cell surface proteins from streptococcus mutans (major bacteria of oral cavity) binds to monocyte surface receptors via sialic acid residues and exerts immune-modulator effects on human monocytes like induction of (TNF- $\alpha$ ), IL-1 $\beta$, and IL-6).

Mean level of salivary (IL-6) in control in this study was in agreement with other investigators ${ }^{26,27}$ who found low levels $(1.4 \pm 1.0 \mathrm{pg} / \mathrm{ml})$ and $(1.8 \pm 4.25 \mathrm{pg} / \mathrm{ml})$ for salivary (IL-6) respectively. 
Salivary levels of IL-6, total sialic acid and total protein in partial edentulous

Majority (75\%) of partial edentulous group were female former smokers, in age group (45-70) years. Low number of teeth caused lower intensity of inflammation compared to dentate periodontitis group as indicated by lower levels of total salivary sialic acid. This result conforms the hypothesis that intensity of periodontal inflammation has been associated with the number of teeth affected ${ }^{28}$ and ensured by no significant difference in the level of sialic acid between partial edentulous group and controls. Similarity of partial edentulous group in total protein with periodontitis. may relate to history of accumulation effects of periodontitis and treatments process and increase in salivary antimicrobial agents. This result consistence with Jawzaly ${ }^{\top}$ and Shetty and Pattabiraman ${ }^{20}$ who found high concentration of total protein in periodontitis and gingivitis.

High value of IL-6 may due to; sex and old ages, that affect salivary secretion and flow rate ${ }^{29}$. This result consistence with Alwan et al. ${ }^{30}$ who found significant difference in the volume of gingival crevicular fluid between chronic periodontitis and healthy control and with Slade et al. ${ }^{31}$ who suggested that C-reactive protein levels among edentulous not similar to periodontal healthy individuals and could be raised by other risk factors; ages, and smoking,

Additionally history of periodontitis and accumulative effects of treatments may affect the volume of saliva and change the equilibrium between the activities of pro-inflammatory and anti-inflammatory cytokines and determine the stage of severity and dissolution of inflammation as stated by Shaker and Hashem ${ }^{12}$ and reported that the total amount of cytokine might be more representative of the disease condition as compared to its concentration. This result also accompanied with Nibali et al. ${ }^{6}$ who reported that IL-6 increase associated to the short-term inflammatory response to therapy and long-term reductions when a clinical improvement in the periodontal status is obtained. This idea was more abundant among former smokers who had history of compromised outcome of periodontal therapy and conform Goutoudi et al. ${ }^{4}$ who found higher concentration of IL-6 in gingival cervicular fluid in diseased sites following treatment, and better clinical result in nonsmokers following treatment of periodontitis.

\section{Relation between ages and Interleukin 6 (IL-6)}

Poor periodontal status in old ages reveals a cumulative effects of periodontal microbial challenges and periodontal treatment, which cause severe diseases in old ages as indicated by high PD and mobility scores in periodontitis and more teeth miss in partial edentulous. This result agrees with Goutoudi et al. ${ }^{32}$ who reported deterioted periodontal status (according to periodontal indices) with age. Also Jawzaly et al. ${ }^{7}$ reported that old age individuals had received more therapy with selective extractions of teeth affected by periodontitis

Relation between (IL-6) and periodontal health status among periodontitis and partial edentulous

Association both IL-6 and sialic acid with periodontitis indices reveals predictor roles of both for severity of periodontitis. Results of IL- 6 consistence with Shaker and Hashem ${ }^{12}$ who found a significant positive correlation between periodontal param- 
eters and serum IL-6, also Alwan et al..$^{30}$ who found a positive significant correlation between quantities of IL-6 in crevicular fluid and tissues inflammation (GI) and destruction (Pd), and with $\mathrm{Ng}$ et al. ${ }^{33}$ who identified significant correlation between alveolar bone loss score and (IL-6).

Accompanying association of (IL-6) and sialic acid with its fraction with indices of periodontitis can be explained by interaction of sialic acid of salivary glycoprotein in pellicle and products of bacteria and immune system. This view the finding of Murray et al. ${ }^{34}$ that tissues destruction and pocket formation and mobility are the result of long accumulation of plaque, and bacteria toxic products and immune system mediators; such as collagenase, metalloproteinase, that are stimulated and produced by IL-6. It is online also with Gani et al. ${ }^{35}$ who proposed releases of inflammatory cytokines, including interleukins IL $1 \alpha$ and IL- 6 and tumor necrosis factor- $\alpha$, as a result of the recruitment and activation of the monocyte/T-lymphocyte axis by bacterial proliferation and / or bacterial products in periodontal pockets. This in turn leads to periodontal tissue destruction.

Negative correlation of IL-6 and TSA with PD and significant positive correlation of IL-6 with $\mathrm{Gl}$ in partial edentulous conforms moderate to severe gingivitis and history of irreversible tissues destruction and pocket formation among partial edentulous group. This result supports Geivelis et al.$^{36}$ who found significant positive correlations between GCF IL-6 levels in sites with gingivitis than in healthy ones and Goutoudi et al. ${ }^{4}$ who found negative correlation between total IL-6 in GCF and PD among patients with chronic periodontitis, and Murata et al. ${ }^{37}$ who found no association between severity of periodontitis and the number of teeth and circulating IL-6 in the elderly. However it is in contrast with previous results suggested a positive correlation of total IL- 6 with disease activity and bleeding as well as PD (Lin et al..$^{38}$ ). Different results in different studies support the idea that the production of inflammatory mediators differs by type of sample and from subject to subject and other several factors; genetic and bacterial composition ${ }^{4}$.

\section{Correlation of IL-6 with total sialic acid and its fractions in periodontitis and partial edentulous}

High correlation of (IL-6) with PSA and total salivary protein may due to the role of (IL-6) in inducing synthesis of other mediator and enzymes and agrees with Gani et al. ${ }^{35}$ who reported that (IL-6) increased hepatic protein synthesis of acute phase proteins (such as richily sialylated $\alpha$-acid glycoprotein, carbon reactive protein, and others) and decreased synthesis of negative reactant proteins.

LSA and FSA in sediment of saliva represent fraction of cells, and high molecular weight mucin (MG1) ${ }^{39}$. Negative correlations LSA and positive FSA with (IL-6) in periodontitis and partial edentulous respectively may explore significant role of terminal sialic acid mucin in both adherence and aggregation by cleaving sialc acid and using it by bacteria depending on the severity of inflammation. Salivary sediment LSA in periodontitis may represent incorporation terminal sialic acid of MG1 with lipo-polysaccharide of gram negative bacteria that can hinder the function of the host defenses as reported by ${ }^{1}$. Additionally degradation of MG1 causes precipitation of its glycoprotein which has sequestering effect for soluble $(\mathrm{IL}-6)^{33}$, and may cause decrease in the level of soluble (IL-6). These results combine also with Gibbons et al. ${ }^{40}$ that terminal sialic acid mucine glycoprotein cleavage create a variety of carbohydrate linkages. 
Correlation of salivary IL-6 with FSA in sediment of partial edentulous may reveal role of IL-6 in regulation of the innate immune response to inflammation by change in glycosylation of glycoprotein of free mucin that induce IL-6 secretion. This result explores the suggestion of ${ }^{41}$ that terminal sialic acid of free glycoprotein mucin is important component of interaction with bacteria protein and prevents colonization by aggregation and swallowing and McBride and Gisslow ${ }^{42}$ who showed a correlation between the amounts of sialic acid released from normal saliva and its aggregating activity. Association may due to IL-6 in modulation protein secretion and glycosylation as suggested by previous studies Groux-Degroote et al. ${ }^{43}$, and Chaudhury et al. ${ }^{44}$ that changes in glycosylation of mucin may induce interleukin 6 secretion.

These observations may reveal anti-inflammatory role of IL- 6 and consistence with Tilg et al..$^{45}$ that (IL-6) regulated acute phase proteins that have anti-inflammatory and immuno-suppressive properties, and may regulate the acute phase response negatively. Also ${ }^{46}$ concluded that IL-6 suppresses IL-I $\beta$ and TNF production induced by LPS and may provide negative feedback effect.

Limitation of the study: Small sample size and lack of longitudinal monitoring the changes in salivary biomarkers from onset of periodontitis, progression and treatment

The findings concluded that salivary sialic acid and IL-6 are oral inflammatory biomarkers in dentate periodontitis. Direction balance of IL-6 toward pro and anti-inflammation can be diagnosed by sialic acid fraction, and affected by age (which determine the number of teeth, and salivary; flow rate and volume), and treatment history.

\section{Acknowledgment}

Thanks first to all study participants for their contributions and periodontic clinic staff of for their support during data collection. Thanks to college of Dentistry / Hawler medical University for their permission to collect data.

Funding: none.

Conflicts of interest: none.

\section{References}

1. Jawzaly JI, Hasan HG, Ahmed BM. Levels of salivary biochemical's in periodontitis and related diseases. Duhok Med J. 2012;6(4):86

2. Murata T, Mizaki H, Senpuku H, Hanada N. Periodontitis and Serum Interleukin-6 in The Elderly. Jpn J Infect Dis. 2001 Apr;54(2):69-71

3. Gemmell E, Seymour GJ. Immunoregulatory control of Th1/Th2 cytokine profiles in periodontal disease. Periodontol 2000. 2004;35:21-41

4. Goutoudi P, Diza E, Arvanitidou M. Effect of periodontal therapy on crevicular fluid interleukin-6 and interleukin-8 levels in chronic periodontitis. Int J Dent. 2012;2012:362905. doi: 10.1155/2012/362905

5. Balto K, Sasaki H, Stashenko P. Interleukin-6 deficiency increases inflammatory bone destruction. Infect Immun. 2001 Feb;69(2):744-50 
6. Nibali L, Fedele S, D’Aiuto F, Donos N. Interleukin-6 in oral diseases: a review. Oral Dis. 2012 Apr;18(3):236-43. doi: 10.1111/j.1601-0825.2011.01867.x.

7. Jawzali Jl. Association between salivary sialic acid and periodontal health status among smokers. Saudi Dent J. 2016 Jul;28(3):124-35. doi: 10.1016/j.sdentj.2016.05.002.

8. Robertst IS. Bacterial polysaccharides in sickness and in health. Microbiology. 1995 Sep;141(Pt 9):2023-31.

9. Shahid SM, Mahboob T. Correlation Between Frequent risk Factors of Diabetic Nephropathy and Serum Sialic Acid. Asian J Biochem. 2006;1:244-50. doi: 10.3923/ajb.2006.244.250.

10. Browning LM, Jebb SA, Mishra GD, Cooke JH, O'Connell MA, Crook MA, et al. Elevated sialic acid, but not CRP, predicts features of the metabolic syndrome independently of BMI in women. Int J Obes Relat Metab Disord. 2004 Aug;28(8):1004-10.

11. Yaghobee S, Khorsand A, Rasouli Ghohroudi AA, Sanjari K, Kadkhodazadeh M. Assessment of interleukin-1beta and interleukin- 6 in the crevicular fluid around healthy implants, implants with periimplantitis, and healthy teeth: a cross-sectional study. J Korean Assoc Oral Maxillofac Surg. 2014 Oct;40(5):220-4. doi: 10.5125/jkaoms.2014.40.5.220.

12. Shaker ZF, Hashem BH. Study the role of proinflammatory and anti- inflammatory cytokines in Iraqi chronic periodontitis patients. J Bagh Col Dent. 2012;24(1):164-9.

13. American Academy of Periodontology Task Force Report on the Update to the 1999 Classification of Periodontal Diseases and Conditions. J Periodontol. 2015 Jul;86(7):835-8. doi: 10.1902/jop.2015.157001.

14. Saxer UP, Mühlemann HR. Epidemiology of periodontal diseases. In periodontology: Muelle HP. (2004) editor: Thiem, Stuttgart: New York:; 2004. p.38-46

15. Carranza FA, Takei HH. Clinical diagnosis. In: Carranza's Clinical Periodontology. Michael G. Newman, Henry H. Takei, Fermin A. Carranza, Perry R. Klokkevold (editor). Saunders Elsevier, 2006. Middle East and African Edition. P. 540-560

16. Löe H. The gingival index, the plaque index and the retention index systems. J Periodontol. 1967 NovDec;38(6):Suppl:610-6.

17. Dowen B, Heintze U. Salivary secretion rate, Buffer capacity, and pH. In: Jorma T, editor. Human Saliva: Clinical Chemistry and Microbiology. Boca Raton: CRC Press; 1989. Vol. 1; p. 25-73.

18. Skoza L, Mohos S. Stable Thiobarbituric Acid Chromophor with Dimethyl Sulphoxide. Biochem J. $1976 \operatorname{Dec} 1 ; 159$ (3):457-62

19. Masami S. Method of measuring lipid bound sialic acid. United states Patent $4837144 ; 6 / 6 / 1989$

20. Shetty PK, Pattabiraman TN. Salivary Glycoproteins As Indicators of Oral Diseases. Indian J Clin Biochem. 2004 Jan;19(1):97-101. doi: 10.1007/BF02872400.

21. Davidson College. Protein determination - Lowry Procedure. Biology 371. Davidson NC 28036; 2000.

22. Shinohara M, Ohura k, Ogata K, Inoue H, Miyata T, Yoshioka M. Relationship between the Sialic Acid Concentration in the Serum and Whole saliva in Rats with Naturally Occuring Gingivitis. J Jpn J Pharmacol. 1994 Jan;64(1):61-3.

23. Elbersol JL, Cappelli D. Acute phase reactants in infection and inflammatory diseases. Periodontol 2000 2000 Jun;23:19-49.

24. Miller CS, King CP Jr, Langub MC, Kryscio RJ, Thomas MV. Salivary biomarkers of existing periodontal disease. J Am Dent Assoc. 2006 Mar;137(3):322-9.

25. Soell M, Holveck F, Schöller M, Wachsmann RD, Klein JP. Binding of Streptococcus mutans SR protein to human monocytes: production of tumor necrosis factor, interleukin 1, and interleukin 6 . Infect Immun. 1994 May;62(5):1805-12.

26. Stuart AD, Brown TD. Alpha2,6-linked sialic acid acts as a receptor for Feline calicivirus. J Gen Virol. 2007 Jan;88(Pt 1):177-86 
27. Rhodus NL, Ho V, Miller CS, Myers S, Ondrey F. NF-kappaB dependent cytokine levels in saliva of patients with oral preneoplastic lesions and oral squamous cell carcinoma. Cancer Detect Prev. 2005;29(1):42-5.

28. Persson RE, Persson GR. The elderly at risk for periodontitis and systemic diseases. Dent Clin North Am. 2005 Apr;49(2):279-92.

29. Al-Azzawi SI, Alwan AM, Salal RH. Influence of age and gender on salivary flow rate in completely edentulous patients. MDJ.2013;10(1):64-8.

30. Alwan AH, Taher MG, Getta HA, Hussain AA. Estimation of the level of Salivary Interleukin 6 (IL-6) and its' correlation with the clinical parameters in patients with periodontal diseases. IOSR J Dent Med Sci.2015 Sep;14(9):82-8.

31. Slade GD, Offenbacher S, Beck JD, Heiss G, Pankow JS. Acute- phase inflammatory Response to Periodontal Disease in the US Population. J Dent Res. 2000 Jan;79(1):49-57.

32. Goutoudi P, Diza E, Arvanitidou M: Effect of periodontal therapy on crevicular fluid interleukin-1beta and interleukin-10 levels in chronic periodontitis. J Dent. 2004;32(7):511-20.

33. Ng PY1, Donley M, Hausmann E, Hutson AD, Rossomando EF, Scannapieco FA. Candidate Salivary biomarkers associated with alveolar boine loss. FEMS Immunol Med Microbiol. 2007 Mar;49(2):252-60.

34. Murray PA, Levine MJ, Reddy MS, Tabak LA, Bergey EJ. Preparation of a sialic Acid-Binding Protein from Streptococcus mitis KS32AR. Infect Immun. 1986 Aug;53(2):359-65.

35. Gani DK, Lashmi D, Kirshman R, Eramad R. Evolution of C-reactive protein and interleukin-6 in the peripheral blood of patients with chronic periodontitis. J Indian Soc Periodontol. 2009 May-Aug;13(2):69-74.

36. Geivelis M, Turner DW, Pederson ED, Lamberts BL. Measurements of interleukin- 6 in gingival crevicular fluid from adults with destructive periodontal disease. J Periodontol. 1993 Oct;64(10):980-3.

37. Murata T, Miyazaki H, Senpuku H, Hanada N. Periodontitis and serum interleukin-6 levels in the elderly. Jpn J Infect Dis. 2001 Apr;54(2):69-71.

38. Lin SJ1, Chen YL, Kuo MY, Li CL, Lu HK. Measurement of gp130 cytokines oncostatin M and IL-6 in gingival crevicular fluid of patients with chronic periodontitis. Cytokine. 2005 May 21;30(4):160-7.

39. Zhang YF, Zheng J, Zheng L, Zhou ZR. Influence of centrifugation treatment on the lubricating properties of human whole saliva. Biosurface Biotribol. 2016;2(3):95-101. doi: 10.1016/j.bsbt.2016.09.001.

40. Gibbons RJ, Etherden I, Moreno EC. Association of neuraminidase-sensitive receptors and putative hydrophobic interactions with high-affinity binding sites for Streptococcus sanguis C5 in salivary pellicles. Infect Immun. 1983 Dec;42(3):1006-12.

41. Marcotte H, Lavoie MC. Oral microbial ecology and the role of salivary immunoglobulin A. Microbiol Mol Biol Rev. 1998 Mar;62(1):71-109.

42. McBride BC, Gisslow MT. Role of sialic acid in saliva-induced aggregation of Streptococcus sanguis. Infect Immun. 1977 Oct;18(1):35-40

43. Groux-Degroote S, Krzewinski-Recchi MA, Cazet A, Vincent A, Lehoux S, Lafitte JJ, et al. IL-6 and IL-8 increase the expression of glycosyltransferases and sulfotransferases involved in the biosynthesis of sialylated and/or sulfated Lewisx epitopes in the human bronchial mucosa. Biochem J. 2008 Feb 15;410(1):213-23.

44. Chaudhury NMA, Proctor GB, Karlsson NG, Carpenter GH, Flowers SA. Reduced Mucin-7 (Muc7) Sialylation and Altered Saliva Rheology in Sjögren's Syndrome Associated Oral Dryness. Mol Cel Proteomics. 2016;15(3):1048-59.

45. Tilg H, Dinarello CA, Mier JW. IL-6 and APPs: anti-inflammatory and immunosuppressive mediators. Immunol Today. 1997 Sep;18(9):428-32.

46. Schindler R, Mancilla J, Endres S, Ghorbani R, Clark SC, Dinarello CA. Correlations and Interactions in the Production of Interleukin-6 (IL-6), IL-1, and Tumor Necrosis Factor (TNF) in Human Blood Mononuclear Cells: IL-6 Suppresses IL-1 and TNF. Blood. 1990 Jan 1;75(1):40-7. 